we have not been searching for nests. Longspurs and Redpolls are common; Greater Scaup, Old Squaw, Pintail are also numerous; Willow Ptarmigan are much in evidence anywhere; and geese (Canada and White-fronted) are seen daily. The Canada Geese are now moulting. Harris' Sparrow also nesits here, but I have not yet seen its nest.

Although the river near camp and the channels between the islands are not good fishing spots we have had the opportunity to test some of the Thelon's rapids about six miles downstream. In one of these I caught a 20-pound Lake Trout. It may be of interest to Blue $\mathbf{J a y}$ readers of the Mammal Notes that this fish's stomach contained a freshly-caught B row n Lemming, Lemmus trimucronatus. Lemming tracks were abundant on the shore of the island from which we were fishing as well as among the large boulders just above the rapids. The lemming probably slipped off one of the rocks and before it could swim to shore was swept over the rapids where the hungry fish awaited it. So not only birds and mammals prey on the abundant lemming, but on occasion fish as well!

Flowers have really come into bloom with a rush. Large tracts are solidly blue with Lupine. Pyrola and Bearberry with pink and white flowers are also prominent. In the bogs the Ledum has blossomed out on the hummocks with its sweetscented white flowers.

All the wonders of nature are even more enjoyable when we write about them in the safeity of the tent! Here at least we are free of the myriads of mosquitoes which make life almost unbearable without repellent or headnets and at best unpleasant even with these protective devices. And we try not to think about the black flies, the tiny tormentors which follow the mosquitoes and, at least to me, are far worse than the mosquitoes.

I trust that readers of the Blue Jay will be interested in some of these plant and wildlife observations made in the Thelon Game Sanctuary, an area which few will be able to visit.

\title{
A Traveller's Birding Recollections
}

by Timothy Dixon, Wells, Somerset

In a previous number of the Blue Jay I was flattered to find myself described as a "world-travelling bird watcher." Most of my experience derives from Europe, Australasia and North America, and these notes are confined to the two latter. They are a selection of a large bundle of memories acquired during my long journeys.

One of my happiest memories is of a short holiday in the Western Australian wheatbelt. In the evening, tine Cockatoos resort to the dams on the farms and congregate noisily in the salmon gums round about. There are rosy-coloured Galahs, white Corellas with lime-yellow underwings, and Major Mitchells with upstanding crests and white plumage delicately suffused with salmon pink. The aboriginals call the Major Mitchell "Chok-a-lok" on account of its cry. Pretty little Chestnut-eared Finches inhabit the castor oil bushes around the lonely homesteads, and flocks of the large, flightless Emu cause small dust storms as they see the station wagon approaching and gallop away.

Very different are the moist and misty forests of Southern Victoria with their 200-foot Victorian mountain ash trees and fronded tree ferns. These forests are the dwelling place of that wonderful singer and mimic, the Superb Lyrebird, of the Eastern Whipbird which takes its name from its "whip-crack" call, of the confiding Pilot Bird (or Downy Pycnoptilus) and the lovely Crimson Rosella Parrat. Some of the Lyrebirds in Sherbrooke Forest are very tame, and once while in close company with one, I whistled many tunes from. symphonic itunes through hymns right down to ragtime. Cocking its head on one side from time to time, it listened intently, and I often wonder whether it remembered and reproduced any of the tunes.

One thinks of the Dominican Gull of New Zealand, 26 inches long, as quite a hefty bird. Yet how insignifi- 
cant it looks in the company of Giant Petrels and Wandering Albatrosses! These birds, all typical of Southern coasts and keen ship-followers, associate freely in pursuit of the ferry boats crossing the Cook strait between Wellington and Picton. Whenever refuse is tipped out, the gulls arrive first. Then the Giant Petrels with their hooded, murderous eyes crash land heavily among the scraps and the gulls fly up like so many sparrows. Ultimately the Albatross is able to manoeuvre itself into the vicinity of the food, of which it takes possession, thrusting viciously at any petrel which might come too close. It seems the arbiter of the Southern ocean expanses, following ships tirelessly with massive hunched shoulders holding the bowed wings rigidly in position: more than any other bird it symbolises the majesty and splendour of the ocean spaces.

Right at the other end of the scale we have one of New Zealand's most interesting birds, the Wry-billed Plover. It is so called because its bill points somewhat to the right. I believe it is the only living bird able to claim this distinction.

Canada is such a large country that it has a varieity of habitats with birds characteristic of each. For me, the song of the Golden-crowned Sparrow will always have a special appeal. At that joyous time in the Northern Hemisphere when the trees seem to become greener every day, the song of the Gclden-crowned Spar. row is at once pure, austere, and sad. The three deliberate notes in cadence, rather low in pitch, strike the ear and heart poignantly with their melancholy.

What a contrast is presented by the ebullient, extroverted notes of the Western Meadowlark! Their blithe, bubbling loudness pours joyfully through the car window as one drives through open country. Another contrast is the fruity squawking of the Yellow-headed Blackbird, eloquent of the marsh-fringed lakes and sloughs.

Lastly I must choose a bird from the Prairies. Around one stretches mile after mile of prairie, not exactly flat, but rising and dipping only just perceptibly-thus enhancing the sensation of vastness. Above is the grey sky. Suddenly, a trickle of notes is poured out, notes unlike those of any other bird save the Veery. No bird is seen, the song. seems to be "utitered by nothingness out of nothingness"-by some disembodied spirit. It is the song of the Sprague's Pipit. To my mind, no bird is more evocative of the wide prairie.

Passing now from birds to human beings, I would like to take this oppontunity of thanking the many Canadian birders who so willingly gave of their time, transport, and bird wisdom in order that my expeditions should be successful.

\section{0 - The Year of the Owls}

by Stuart Houston, Saskatoon

The year 1960 máy be noted for many things, but for me and many others in the Yorkton area it will always be remembered as "the year of the owls". It got off to a good start on January 2, when I drove up to High Hill to band a Barred Owl caught by Steve and Anton Waycheshen. The Barred Owl is a new species on the Saskatchewan list (see Blue Jay 17:94, 1959 and 18:5, $1960)$ and this was the first individual to be banded in Saskatchewan.

Then came the onslaught of Boreal (Richardson's) Owls. Gary Anweiler snared the first one on
January 7 (see Blue Jay 18:61-63, 1960). By January 22, we had banded four and Gary was keeping a fifth for study purposes. We arranged to show Gary's bird on CKOS-TV, Yorkton, on Monday evening, January 25, and meanwhile Martin Busch of Calder caught another. During the special 15-minute program devoted exclusively to a discussion of Richardson's Owls, Gary and I each had an owl perched on our wrist, secured by falconer's jesses. The owls snapped and flapped their wings at the audience and from that moment "Richardson's radiology for three years. His new address is 2401 Hanover Ave, Saskatoon. 